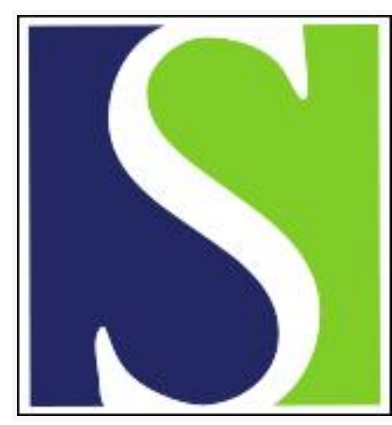

Scand J Work Environ Health 1994;20(3):180-183

https://doi.org/10.5271/sjweh.1411

Issue date: 01 Jun 1994

Early indicators of renal dysfunction in silicotic workers.

by Boujemaa W, Lauwerys R, Bernard A

Affiliation: Unit of Industrial Toxicology and Occupational Medicine, Catholic University of Louvain, Faculty of Medicine, Brussels, Belgium.

This article in PubMed: www.ncbi.nlm.nih.gov/pubmed/7973489 


\title{
Early indicators of renal dysfunction in silicotic workers
}

\author{
by Wided Boujemaa, MD, Robert Lauwerys, MD, Alfred Bernard, PhD ${ }^{1}$
}

\begin{abstract}
BOUJEMAA W, LAUWERYS R, BERNARD A. Early indicators of renal dysfunction in silicotic workers. Scand J Work Environ Health 1994;20:180-3.

OrJectives - The aim of the study was to determine whether silicosis is associated with renal alterations detectable in urinary or blood-borne indicators of nephrotoxicity.

MEтноDS - The study used a cross-sectional design. The subjects comprised 116 male workers who had been exposed to silica for at least two years and had been diagnosed as having silicosis and 61 age-matched referents. The considered outcome measures were the concentrations of beta - -microglobulin and creatinine in serum and the urinary excretion of albumin, retinol-binding protein, and beta-N-acetylD-glucosaminidase.

RESULTS - Compared with the referents, the silicotic subjects excreted, on the average, slightly higher amounts of albumin, retinol-binding protein, and beta- $\mathrm{N}$-acetyl-D-glucosaminidase. This increase did not correlate with the duration of exposure or the stage of silicosis and was not associated with an

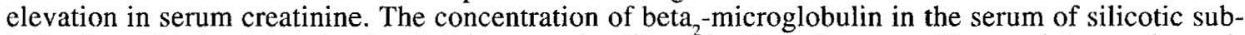
jects showed a tendency to rise that became significant in the subgroup with pseudotumoral opacities. This effect, which did not correlate with markers of nephrotoxicity, is however more likely the consequence of silicosis-associated inflammatory reactions than of decreased renal filtration.

Conclusions - The present study confirms that silicosis is associated with some infraclinical renal alterations. However, in the absence of a relationship with length of exposure or severity of silicosis, the implication of silica in their causation needs to be examined further.
\end{abstract}

KEY TERMS - albuminuria, enzymuria, nephrotoxicity, proteinuria, retinol-binding protein, silicosis.

An association between occupational exposure to silica and chronic nephropathy has been suspected for many years. Animal studies have demonstrated that silica can produce a dose-related nephropathy that is primarily tubular and is associated with interstitial inflammatory reactions and fibrosis $(1,2)$. Several cases of nephropathy in workers exposed to silica have been reported (3-9). The nephropathy has usually consisted of a focal or segmental, rapidly progressive glomerulonephritis without significant immune-complex deposits and with variable degrees of tubular degeneration. The nephropathy has been described even in the absence of silicosis (10). Abnormally elevated levels of silicon have been found in the kidneys of patients with silica-associated nephropathy, and the examination of biopsy materials has revealed silica deposits in epithelial cells and in subepithelial and subendothelial areas of the basement membranes. Altogether these findings suggest that silica may exert direct toxicity on the kidneys although in some cases the nephrotoxicity might also be mediated by the immune system $(3,9)$. The hypothesis of chronic nephropathy in association with

1 Unit of Industrial Toxicology and Occupational Medicine, Catholic University of Louvain, Faculty of Medicine, Brussels, Belgium.

Reprint requests to: Professor A Bernard, Unité de Toxicologie Industrielle et de Médecine du Travail, $30.54 \mathrm{Clos}$ Chapelle-aux-Champs, B-1200 Bruxelles, Belgium. silica exposure is supported by several epidemiologic studies reporting an increased risk of end-stage renal disease or mortality from renal diseases in relation with silica exposure $(10-12)$. Additional evidence has been provided by a recent cross-sectional study showing an excess of albumin, alpha, - microglobulin, and beta-N-acetyl-D-glucosaminidase in the urine of a small group of graphite workers (13). The objective of the present cross-sectional study was to confirm the latter findings on a larger group of subjects suffering from silicosis and to examine the possible relations between renal alterations and the duration of exposure or severity of silicosis.

\section{Subjects and methods}

The study was carried out on 116 male workers with diagnosed silicosis compensated by the Belgian Occupational Disease Fund. All of the workers had been exposed to silica for at least two years in underground mining. It was ascertained that none of them was suffering from diseases that could involve the kidneys (hypertension, diabetes, nephrolithiasis, diabetes) or had been exposed to known nephrotoxic substances such as heavy metals or solvents. The mean duration of exposure to silica was 14.9 (range 2 -35) years, and on the average they had not been exposed for 23.2 years (table 1).

The reference group consisted of 61 age-matched male subjects selected from the general population. 
Each subject provided a sample of blood and urine and completed a questionnaire collecting information on the subjects' medical and employment history and their consumption of tobacco, drugs, and alcohol. Chest radiographs were taken of all of the silicotic workers, and the films were read by experienced pneumonologists of the Belgian Occupational Disease Fund. Radiological opacities were categorized as punctiform (p), micro or nodular ( $m$ or $n)$, or pseudotumoral (A, B, or C), and their density was divided into three grades according to the ILO classification of pneumoconiosis (14). The concentrations of albumin, retinol-binding protein (RBP) and beta microglobulin $\left(\beta_{2}-m\right)$ in serum or urine were determined by latex immunoassay (15). Creatinine was measured by Jaffé's method, and the activity of beta-N-acetyl-D-glucosaminidase (NAG) in urine was assayed by the fluorimetric method of Tucker et al (16).

Statistical tests were done with Statview SE software (Abacus Concept, 1979). All of the variables (except age) were log-transformed before the analysis. The Kolmogorov-Smirnov test was applied to check the normality of the distributions, whereas the homogeneity of variances was ascertained by the Ftest. Differences between the exposed and reference subjects were assessed by Student's t-test (twotailed), and the relations with radiological opacities were examined by a one-way analysis of variance followed by Scheffé's multiple comparison test. Prevalences of abnormally elevated values were calculated with the geometric mean plus two geometric standard deviations of the values observed for the referents as the upper limit of normal. The prevalences of abnormal values among the silicotic workers and the referents were compared with the chisquare test with Yates' correction. Pearson correlation coefficients were calculated to examine the relations between renal parameters, whereas the determinants of the indicators of nephrotoxicity were traced in a stepwise regression analysis. Results were considered statistically significant at $\mathrm{P}<0.05$.

\section{Results}

Compared with their age-matched referents, the subjects who had been exposed to silica had, on the average, significantly higher concentrations of albumin, RBP, and NAG in their urine (table 1). No significant difference was found in the mean values of creatinine and $\beta_{2}-m$ in serum, although the latter showed a slight tendency to be increased in silicotic workers $(P=0.08)$. The prevalences of abnormally elevated values of the markers did not differ between the groups (results not shown).

The correlation analysis showed a significant degree of correlation between albumin, RBP, and NAG in the urine of both the reference and silicotic subjects [correlation coefficient ( $\mathrm{r}$ ) between 0.25 and 0.69]. None of these markers correlated however with creatinine or $\beta_{2}-m$ in serum, except the urinary NAG, which was weakly associated with serum $\beta_{2}-\mathrm{m}$ among the referents $(\mathrm{r}=0.28, \mathrm{P}=0.03)$. The concentrations of $\beta_{2}-\mathrm{m}$ and creatinine in serum correlated, but the association was much stronger for the referents $(r=0.59, P=0.0001)$ than for the silicotic subjects $(r=0.19, P=0.04)$. Among the referents, the urinary activity of NAG and the serum concentration of $\beta_{2}-\mathrm{m}$ were related to age $(\mathrm{r}=0.30$ and 0.45 , $P=0.02$ and 0.0002 , respectively).

The determinants of the urinary or serum indicators of nephrotoxicity in the silicotic subjects were examined by stepwise regression with age, duration of exposure, size, and density of lung opacities being used as the predictors. Apart from the associations of age with urinary NAG and serum $\beta_{2}-m$, the only significant finding that emerged from this analysis was a positive correlation between the size of opacities and the serum levels of $\beta_{2}-\mathrm{m}(\mathrm{r}=0.3, \mathrm{P}=$ $0.0007)$. To assess further the influence of opacity size, we compared the mean values of the different markers for subjects with punctiform, micro or nodular, or pseudotumoral opacities (table 2). Whereas urinary markers and serum creatinine on the average did not differ between the subgroups, the mean

Table 1. Characteristics and renal parameters of the workers with silicosis and their referents. (NS $=$ not significant, Alb $=$ albumin, $R B P=$ retinol-binding protein, $\beta_{2}-m=$ beta $_{2}-$ microglobulin, NAG = beta- $N$-acetyl-D-glucosaminidase)

\begin{tabular}{|c|c|c|c|c|c|c|c|c|c|}
\hline \multirow[b]{2}{*}{$\begin{array}{l}\text { Characteristic or } \\
\text { renal parameter }\end{array}$} & \multicolumn{4}{|c|}{ Silicotic subjects $(N=116)$} & \multicolumn{5}{|c|}{ Referents $(N=61)$} \\
\hline & $\begin{array}{l}\text { Arith- } \\
\text { metic } \\
\text { mean }\end{array}$ & Range & $\begin{array}{c}\text { Geometric } \\
\text { mean }\end{array}$ & Range & $\begin{array}{l}\text { Arith- } \\
\text { metic } \\
\text { mean }\end{array}$ & Range & $\begin{array}{c}\text { Geometric } \\
\text { mean }\end{array}$ & Range & P-value \\
\hline Age (years) & 60.2 & $31.5-84$ & . & - & 59.9 & $37-87.8$ & . & . & NS \\
\hline Duration of exposure (years) & . & . & 14.9 & $2-35$ & . & - & . & . & . \\
\hline $\begin{array}{l}\text { Delay after cessation } \\
\text { of exposure (years) }\end{array}$ & . & . & 23.2 & $0-30$ & . & . & . & . & . \\
\hline Creatinine in serum $\left(\mathrm{mg} \cdot \mathrm{I}^{-1}\right.$ a) & . & $\cdot$ & 10.0 & $7.7-13.5$ & . & - & 10.0 & $6.2-19.1$ & NS \\
\hline Alb in urine $\left(\mathrm{mg} \cdot \mathrm{g}\right.$ creatinine $\left.{ }^{-1} \mathrm{a}\right)$ & . & . & 11.1 & $2.3-870$ & . & . & 7.2 & $1.2-430$ & 0.017 \\
\hline RBP in urine $(\mu \mathrm{g} \cdot \mathrm{g}$ creatinine $-1 \mathrm{a})$ & . & . & 84.3 & $24-780$ & . & . & 63 & $16.3-980$ & 0.0045 \\
\hline$\beta_{2}-m$ in serum $\left(\mathrm{mg} \cdot \mathrm{I}^{-1}\right)$ & . & . & 1.86 & $0.03-7.5$ & . & . & 1.70 & $1.05-3.4$ & $\begin{array}{c}\text { NS } \\
(P=0.08)\end{array}$ \\
\hline NAG in urine $\left(U I \cdot g\right.$ creatinine $^{-1}$ a) & . & . & 1.64 & $0.09-13$ & . & - & 0.68 & $0.10-7.1$ & 0.0001 \\
\hline
\end{tabular}

a $1 \mathrm{mg}$ or $\mathrm{UI} \cdot \mathrm{g}$ creatinine $\mathrm{c}^{-1}=0.113 \mathrm{mg}$ or $\mathrm{Ul} \cdot \mathrm{g}$ creatinine $\mathrm{-}^{-1}$. 
Table 2. Renal parameters for the silicotic workers according to the size of their radiological opacities and for the referents. ( $\mathrm{Alb}=$ albumin, $\mathrm{RBP}=$ retinol-binding protein, $\beta_{2}-\mathrm{m}=$ beta $_{2}$ - microglobulin, $\mathrm{NAG}=$ beta-N-acetyl-D-glucosaminidase)

\begin{tabular}{|c|c|c|c|c|c|c|c|c|}
\hline \multirow{3}{*}{ Parameter } & \multicolumn{6}{|c|}{ Silicotic workers } & & \\
\hline & \multicolumn{2}{|c|}{$\begin{array}{l}\text { Punctiform } \\
\text { opacities } \\
(\mathrm{N}=37)\end{array}$} & \multicolumn{2}{|c|}{$\begin{array}{l}\text { Micro or nodular } \\
\text { opacities } \\
(\mathrm{N}=36)\end{array}$} & \multicolumn{2}{|c|}{$\begin{array}{l}\text { Pseudotumoral } \\
\text { opacities } \\
(N=43)\end{array}$} & \multicolumn{2}{|c|}{$\begin{array}{l}\text { Referents } \\
(\mathrm{N}=61)\end{array}$} \\
\hline & $\begin{array}{l}\text { Geo- } \\
\text { metric } \\
\text { mean }\end{array}$ & Range & $\begin{array}{l}\text { Geo- } \\
\text { metric } \\
\text { mean }\end{array}$ & Range & $\begin{array}{l}\text { Geo- } \\
\text { metric } \\
\text { mean }\end{array}$ & Range & $\begin{array}{l}\text { Geo- } \\
\text { metric } \\
\text { mean }\end{array}$ & Range \\
\hline 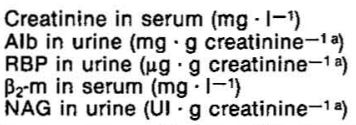 & $\begin{array}{c}9.9 \\
11.6 \\
86.7 \\
1.64 \\
1.59\end{array}$ & $\begin{array}{c}7.7-13.5 \\
3.1-342 \\
40-188 \\
0.85-3.0 \\
0.26-5.0^{\star}\end{array}$ & $\begin{array}{l}10.1 \\
11.7 \\
86.7 \\
1.92 \\
1.69\end{array}$ & $\begin{array}{l}7.7-12.4 \\
3.4-869 \\
24-334 \\
1.1-7.2 \\
0.1-5.9^{\star}\end{array}$ & $\begin{array}{l}10.1 \\
10 \\
80.7 \\
2.0 \\
1.66\end{array}$ & $\begin{array}{c}8.2-13.2 \\
2.3-398 \\
27-780 \\
0.99-2.9^{*} \\
0.54-10^{*}\end{array}$ & $\begin{array}{l}10 \\
7.2 \\
63 \\
1.70 \\
0.68\end{array}$ & $\begin{array}{r}6.2-19.1 \\
1.2-430 \\
16.3-980 \\
1.05-3.4 \\
0.10-7.1\end{array}$ \\
\hline
\end{tabular}

a $1 \mathrm{mg}$ or $\mathrm{Ul} \cdot \mathrm{g}$ creatinine $\mathrm{e}^{-1}=0.113 \mathrm{mg}$ or $\mathrm{Ul} \cdot \mathrm{g}$ creatinine -1

* Significantly different from the reference.

* Significantly different from the group with punctiform opacities.

values of serum $\beta_{2}-m$ increased in parallel with the size of the opacities.

\section{Discussion}

We found that workers with silicosis excreted slightly more albumin, RBP, and NAG in their urine than age-matched referents did. These results confirm the recent observations of $\mathrm{Ng}$ et al (13), who reported an increased urinary excretion of albumin, NAG and alpha ${ }_{1}$-microglobulin in 33 silica workers in comparison with 16 referents, on a much larger number of subjects. Since alpha-microglobulin is a marker of proximal tubule dysfunction comparable to RBP (17), the pattern of effects observed among our workers and among those examined by $\mathrm{Ng}$ et al (13) can be considered identical. Both studies were also carried out on workers who had stopped exposure several years earlier; therefore renal alterations associated with silica exposure may be irreversible.

It is important to stress however that the silicotic workers examined by us were not distinguishable from their referents in the prevalences of abnormally elevated values of the renal markers. The difference between both groups was thus restricted to a very slight shift in the distribution of urinary markers. This observation, combined with the fact that the serum creatinine values were, in most cases, normal, testifies to very discrete effects that do not impair renal function. An elevation of $\beta_{2}$-m was found in serum, but this effect, which correlated with the severity of silicosis and not with markers of nephrotoxicity, is more likely the consequence of some silicosis-associated inflammatory changes than of a decline in renal filtration. It would be premature, however, to conclude from these observations that renal effects associated with silicosis have no clinical significance. The possibility of a selection bias inherent to any cross-sectional study appears especially probable here since the workers were examined an average of 23 years after the cessation of exposure. This possibility is also suggested by the epidemio- logic evidence $(10-12)$ of an excess of end-stage renal diseases or of mortality from renal diseases in relation with silica exposure.

Although our results are consistent with the hypothesis of a nephrotoxic action of silica, they provide no correlational evidence of the implication of silica in their causation. Indeed, no association could be demonstrated between renal alterations and the duration of exposure or the severity of silicosis. This finding might be due to the long delay between removal from exposure and the examination (survival bias), and probably also to the inadequacy of the indicators used to evaluate the exposure to silica. But it might also suggest that silicosis and renal alterations are not linked causally, but instead through their common associations with a third factor. This third factor could be, for instance, some kind of a predisposition to immunologically based reactions that would favor the development of silicosis but also, independently of the exposure to silica, the appearance of abnormalities in other organs, including the kidney. The lack of a relationship with the stage of silicosis is however in agreement with the view expressed in the literature $(3,9)$ that silica-associated nephropathy is not simply a complication of silicosis, but might result from a nephrotoxic action of soluble silica absorbed by the lungs. This possibility, supported by animal data $(1,2)$, could be tested by studying the dose-response effect relations between signs of renal dysfunction and indicators of the internal dose of silica in a cross-sectional study on currently exposed workers without silicosis.

\section{Acknowledgments}

We gratefully acknowledge Dr R Van de Weyer (Belgian Occupational Disease Fund) for allowing us to examine silicotic subjects, $\mathrm{Mr} \mathrm{X}$ Dumont and $\mathrm{Mr}$ $\mathrm{H}$ Bauer for their expert technical assistance and $\mathrm{Dr}$ JC Daniel from Rhône-Poulenc Industrie, France, for the gift of batches of polystyrene latex particles (ESTAPOR K109). 
This study was supported by the Fonds de la Recherche Scientifique Médicale (Belgium) and the Commission of the European Communities.

\section{References}

1. Policard A, Collet A. Etude expérimentale des lésions rénales provoquées par la silice. J Urol Med Chir 1954;60:164-71.

2. Newberne PM, Wilson RB. Renal damage associated with silicon compounds in dogs. Proc Natl Acad Sci USA $1970 ; 65: 872-5$.

3. Osorio AM, Thun MJ, Novak RF, Jay Van Cura E, Avner ED. Silica and glomerulonephritis: case report and review of the literature. Am J Kidney Dis 1987;9:224-30.

4. Giles RD, Sturgill BC, Suratt PM, Bolton WK. Massive proteinuria and acute renal failure in a patient with acute silico-proteinosis. Am J Med 1987;64:336-42.

5. Sherson D, Jorgensen F. Rapidly progressive crescenteric glomerulonephritis in a sandblaster with silicosis. Br J Ind Med 1989;9:675-6.

6. Analich F, Lahez C, Picazo ML, Monero A, Arribas JR, Martinez Ara J, et al. Polyarteritis nodosa and necrotizing glomerulonephritis associated with longstanding silicosis. Nephron 1989;51:544-7.

7. Bonnin A, Mousson C, Justrabo E, Tauter Y, Chalopin JM, Rifle G. Silicosis associated with crescentic IgA mesangial nephropathy. Nephron 1978;47:229 30.

8. Dracon M, Noel C, Wallaert B, Dequiedt P, Lelievre $\mathrm{G}$, Tacquet A. Glomérulonéphrites rapidement progressives chez les mineurs de charbon pneumoconiotiques. Néphrologie 1990;11:61-5.
9. Sauvaget P, Pairon JC, Rostocker J, Belghiti D, Brochard P. Les glomérulonéphrites induites par une exposition professionnelle à la silice; mise au point à partir d'une observation. Arch Mal Prof 1990;51:593-5.

10. Steenland NK, Thun MJ, Ferguson CW, Port FK. Occupational and other exposures associated with male end-stage renal disease: a case-control study. Am J Public Health 1990;2:153-7.

11. Marsh GM, Enterline PE, Stone RA, Henderson VL. Mortality among a cohort of US man-made mineral fibers workers. J Occup Med 1990;32:594-604.

12. Goldsmith JR, Goldsmith DF. Fiberglass or silica exposure and increased nephritis or ESDR (end-stage renal disease). Am J Ind Med 1993;23:873-81.

13. Ng TP, Ng YL, Lee HS, Chia KS, Ong HY. A study of silica nephrotoxicity in exposed silicotic and nonsilicotic workers. Br J Ind Med 1992;49:35-7.

14. International Labour Office (ILO). Guidelines for the use of ILO international classification of radiographs of pneumonoconiosis. ILO, Geneva, 1980. Occupational health safety series, no 22 .

15. Bernard A, Lauwerys R. Continuous flow system for the automation of latex immunoassay by particle counting. Clin Chem 1983;29:1007-11.

16. Tucker SM, Boyd PJR, Thompson AE, Price RG. Automated assay of $\mathrm{N}$-acetyl glucosaminidase in normal and pathological urine. Clin Chim Acta 1979;62:3339.

17. Bernard A, Lauwerys R. Proteinuria: changes and mechanisms in toxic nephropathies. Crit Rev Toxicol 1991;21:373-405.

Received for publication: 27 July 1993 